\title{
Determinants Model in Reducing HIV-Related Stigma in Health care Workers: A Systematic Review
}

\author{
Sri Handayani ${ }^{1,2 *(\mathbb{D})}$, Alimin Maidin ${ }^{2}$, Agus Bintara Birawida $^{2}$, Suriah Suriah $^{2}$, Ansariadi Ansariadi $^{2}$, Rahayu Indriasari $^{2}$ D \\ Stang Stang ${ }^{2}$ \\ ${ }^{1}$ Sekolah Tinggi Ilmu Kesehatan Tamalatea, Makassar 90245, Indonesia; ${ }^{2}$ Department of Nutrition, Faculty of Public Health, \\ Hasanuddin University, Makassar 90245, Indonesia.
}

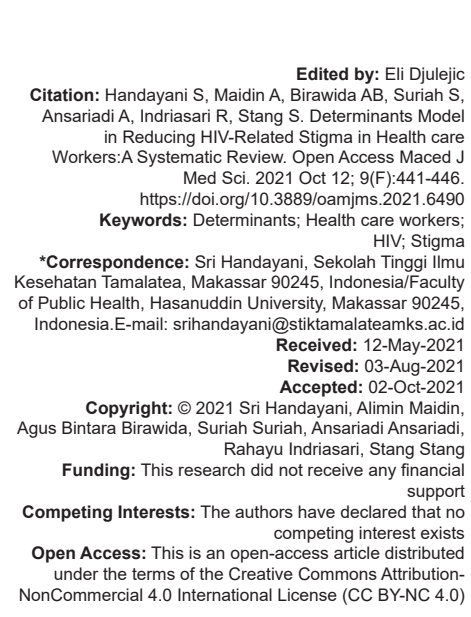

Abstract

BACKGROUND: The stigma accepted by people living with HIVIAIDS (PLWHA) is a major obstacle in HIV prevention, especially from health workers.

AIM: This study aims to determine the factors associated with HIV stigma among health workers.

METHODS: This systematic review was conducted using the 2015 PRISMA guidelines. All publications review was conducted using four bibliographic databases. In the final screening stage, the authors read the full text of the remainder of the article and held back studies that were consistent with inclusion criteria, focusing on HIV-related stigma determinants published in 2010-2020.

RESULTS: The stigma that comes from health workers to PLWHA can come from personal beliefs or a lack of personal confidence, which can be derived from self-confidence, self-confidence, knowledge, working time, institutional support or policies from the workplace, religious, and sociocultural values that create discriminatory behavior when dealing with PLWHA. The created stigma can reduce social interactions and the quality of life of PLWHA.

CONCLUSION: It is important to find determinants to formulate appropriate intervention plans in reducing HIV-related stigma, especially among health workers.

\section{Introduction}

HIVIAIDS prevalence globally is still rather high [1], [2]. The World Health Organization (WHO) data mention around $54 \%$ of HIV-positive cases were new cases [3], [4].A myriad of efforts was done to reduce HIVIAIDS cases [5], however, stigmas are still an important aspect and often become the main hurdle in reducing HIVIAIDS cases [6], [7], [8], [9].

Stigmas on people living with HIVIAIDS (PLWHA) not only occur from common society members but also occur on health care workers [7]. This is in conjunction with the research result done by Nyblade et al., 2018, which stated that health care workers have a stigma and differentiates PLWHA. On health-care facilities, the manifestation of the stigma was widely documented [10], from direct rejection of treatment, below standard treatment, verbal and physical abuse, to a more soft form of rejection such as making them wait longer or surrenders the care to the more junior member of the health-care team [11]. It can be concluded that stigma is the main obstacle in treating those who are seeking preventive measure and to uphold their own quality of life [6]. Therefore, there needs to be a comprehensive and holistic care in the HIVIAIDS epidemic which can cause a bad impact not only on health sector but also socioeconomical development of a nation [12].

\section{Methods}

\section{Search strategy}

Search is conducted using online journal database which provides articles in PDF format such as PubMed, Scinapse, Elsevier, and Google Scholar. Articles taken were imported into Mendeley Library. Main keywords used during the search process are HIV* and Stigma* And Health care Workers* And Risk Factor* OR Determinant.

\section{Inclusion/Exclusion criteria}

Criteria that were integrated in the database are (1) focus on stigma determinant related to HIV, 
(2) published in the past 10 years (2010-2020), and (3) articles full text published in English. Exclusion criteria are (1) Review/Editorial (2) Conference Process (3) Systematic Review/Literature Review (4) Protocol Study, and (5) Meta-Analysis.

\section{Data extraction}

The study selection process is in accordance with Data Extraction Based on PRISMA 2015 Guidelines in Figure 1.

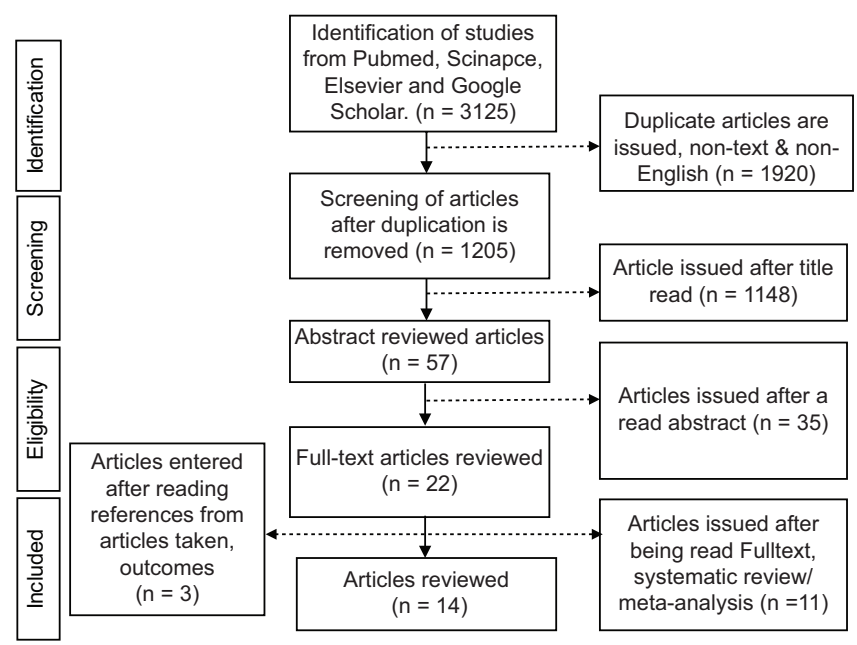

Figure 1: Flowchart literature

\section{Data synthesis}

Author filters all publication by reading the title and abstract. In the final filtering phase, author reads the complete text of the remaining articles and withholds the study which is in line with inclusion criteria. The summary of the selected articles is recorded which consists of; author, year of publication, country of publication, title, subject/sample, study objective, study design, outcome/ results, and determinants of stigma (Table 1).

\section{Literature search}

The literature was accessed by identifying articles based on inclusion and exclusion criteria. This review article was compiled thematically using PRISMA 2015 because is the right method for filtering articles to be compiled in a systematic system consisting of various studies that have relevant methods, concepts, and results.

\section{Results and Discussion}

A total of 3125 articles are taken from four data basis. After the deletion of duplicated, 1205 articles were withhold. Based on the inclusion and exclusion criteria,
57 articles were selected. Manual bibliographical reference search of articles identified three extra articles so in total of 14 articles were reviewed. Table 1 shows research synthesis on determinant model in reducing HIV-related stigma on health care workers.

\section{workers}

\section{Stigma and discrimination on health care}

Stigma and discrimination are not only carried out by ordinary people who do not have sufficient knowledge about HIVIAIDS, but can also be carried out by health-care providers. According to research by Wilandika (2019), the stigma associated with HIV in health services can hinder PLWHA from seeking care if they have previously experienced unwanted treatment or the confidentiality of their HIV status is not respected. The emergence of stigma against PLWHA in health services is closely related to the attitudes and behaviors shown by health workers in providing health services, be they nurses, doctors, or other health workers [23].

Nyblade's (2019) study shows that there is a decrease in professional attitudes among health-care providers who care for patients with HIV infection. The stigma that occurs in the health-care environment is a serious problem in the health-care system. If a patient is infected with HIV and feels stigmatized by health workers, it can affect the quality of care, the patient's quality of life, and involvement in the care process [24]. The following summary on determinant related stigma on health care workers at Table 2.

The occurrence of stigma against PLWHA by health workers is influenced by several things according to the research that was reviewed as follows:

\section{Knowledge of HIVIAIDS}

Knowledge of HIVIAIDS greatly influences how individuals behave towards people with HIV/ AIDS [25]. Stigma and discrimination against PLWHA arise in relation to ignorance or misunderstanding of the mechanisms of HIV transmission, overestimation of the risk of contracting HIV through casual contact, and disproportionately negative attitudes toward social groups affected by the HIVIAIDS epidemic [26], [27]. In line with research conducted by Vorasane (2017) which states that across health professionals, lower levels of HIVIAIDS knowledge are associated with higher levels of stigmatizing attitudes toward PLWHA [7].

\section{Perceptions about PLWHA}

Perceptions of people living with HIV or people with AIDS will greatly influence how that person will behave and behave toward PLWHA [14], [19]. Subedi (2019) states that stigma and discrimination against PLHIV are related to the perception of shame and 
Table 1: Research synthesis on determinant model in reducing HIV-related stigma on health care workers

\begin{tabular}{|c|c|c|c|c|}
\hline No. & Author/year/place & Subject/sample & Study objective & Study outcome/result \\
\hline 1 & $\begin{array}{l}\text { Tran et al., } 2019 . \\
\text { Vietnam [8] }\end{array}$ & 1016 patients & $\begin{array}{l}\text { Grades the stigmatization and discrimination } \\
\text { that is experienced by people living with HIV } \\
\text { (PLWHA) in multitudes of settings such as } \\
\text { social, family, community, and health-care facility } \\
\text { in Vietnam }\end{array}$ & $\begin{array}{l}\text { Stigma level from society or community reported by PLWHA is linked with } \\
\text { socioeconomical status whereas stigma in health-care facility is reported } \\
\text { based on knowledge and attitude of the health care workers }\end{array}$ \\
\hline 2 & $\begin{array}{l}\text { Xie et al., } 2018 . \\
\text { China [13] }\end{array}$ & $\begin{array}{l}63 \text { medical staff with } 2 \\
\text { weeks interval; and structural } \\
\text { validation with } 349 \text { medical } \\
\text { staff from } 52 \text { hospitals }\end{array}$ & $\begin{array}{l}\text { The purpose of this research is to validate the } \\
\text { stigma scale on HIVIAIDS health-care providers } \\
\text { between medical staff in China }\end{array}$ & $\begin{array}{l}\text { Stigma was insignificantly different }(p>0.05) \text { in terms of gender, career } \\
\text { (physician and nurses), level of education, and whether or not the person } \\
\text { in question has treated AIDS. There were connections between culture, } \\
\text { level of education, career, gender, and knowledge regarding HIVIAIDS in } \\
\text { China }\end{array}$ \\
\hline 3 & $\begin{array}{l}\text { Nairet al., 2019. } \\
\text { Bihar, India [14] }\end{array}$ & $\begin{array}{l}71 \text { participants, including } 35 \\
\text { individuals infected with HIV } \\
\text { and member of society and } \\
26 \text { health-care providers }\end{array}$ & $\begin{array}{l}\text { To grade attitudes regarding individual infected } \\
\text { with HIV between health-care providers and } \\
\text { members of society }\end{array}$ & $\begin{array}{l}\text { Several factors which contribute to stigma on health care workers: } \\
\text { Perception regarding HIV; the disclosure of HIV status without consent; } \\
\text { and inadequate knowledge and fear between the health-care providers in } \\
\text { regard to the infection of HIV and also the policy in health facilities }\end{array}$ \\
\hline 4 & $\begin{array}{l}\text { (Yang et al., 2018). } \\
\text { United States [15] }\end{array}$ & $\begin{array}{l}558 \text { health care workers } \\
\text { from } 12 \text { of the } 17 \text { hospitals in } \\
\text { Vientiane }\end{array}$ & $\begin{array}{l}\text { To grade HIV-related stigma between health- } \\
\text { care providers in Laos and examine the related } \\
\text { factors in HIVIAIDS stigma between physician } \\
\text { and nurses }\end{array}$ & $\begin{array}{l}\text { Lower HIVIAIDS-related knowledge in relations with higher stigma level } \\
\text { with individuals infected with HIVIAIDS. Stigmatized treatment, fear of } \\
\text { AIDS, and prejudice were observed to be lower in health care workers with } \\
\text { more experience in treating patients with HIVIAIDS }\end{array}$ \\
\hline 5 & $\begin{array}{l}\text { Befekadu et al., } 2017 . \\
\text { South Africa [11] }\end{array}$ & $\begin{array}{l}16 \text { participants are PLWHA } \\
\text { that is treated in two selected } \\
\text { hospitals in Amhara region } \\
\text { in Ethiopia }\end{array}$ & $\begin{array}{l}\text { To explore factors that are caused by stigma and } \\
\text { discrimination to people infected with HIV in two } \\
\text { hospitals in rural Ethiopia }\end{array}$ & $\begin{array}{l}\text { Participants viewpoints are grouped into fear of contact, slow service, } \\
\text { below standard treatment, rejection of treatment, rudeness of the health- } \\
\text { care providers, secrecy offence, and bad follow-up for patient infected with } \\
\text { HIV }\end{array}$ \\
\hline 6 & $\begin{array}{l}\text { Prinsloo et al., } 2017 . \\
\text { South Africa [16] }\end{array}$ & 110 Health care Workers & $\begin{array}{l}\text { To determine the size of the stigma and } \\
\text { discrimination in relation with HIVIAIDS (SAD) } \\
\text { and factors that are affecting health-care settings }\end{array}$ & $\begin{array}{l}\text { Stigma to patient from health care workers participating in the training } \\
(\mathrm{OR}=13.46, p=0.005) \text {. In the } 2^{\text {nd }} \text { hospital, only infection risks are felt to } \\
\text { have a significant effect on stigma }\end{array}$ \\
\hline 7 & $\begin{array}{l}\text { Jabbour et al., 2018. } \\
\text { South Carolina [17] }\end{array}$ & $\begin{array}{l}1747 \text { members of } \\
\text { congregation faith- } \\
\text { based African-American } \\
\text { organization }\end{array}$ & $\begin{array}{l}\text { To examine the connections between social } \\
\text { factors in a religion-based settings (including } \\
\text { religiousness and proximity with individuals } \\
\text { infected with HIVIAIDS) and HIV stigma }\end{array}$ & $\begin{array}{l}\text { Female }(p=0.001) \text {, higher education }(p<0.001) \text {, knowing someone with } \\
\text { HIVIAIDS }(p=0.01) \text { and knowing someone who is gay }(p<0.001) \text {, lack of } \\
\text { religiousness is linked with a lower level of stigma and lower chances of } \\
\text { stigma }(p<0.05)\end{array}$ \\
\hline 9 & $\begin{array}{l}\text { Vorasane, } 2017 . \\
\text { Laos [7] }\end{array}$ & $\begin{array}{l}558 \text { health care workers } \\
\text { from } 12 \text { of the } 17 \text { hospitals in } \\
\text { Vientiane }\end{array}$ & $\begin{array}{l}\text { The purpose of this study was to assess HIV } \\
\text { stigmatizing attitudes within Laotian health-care } \\
\text { service providers and examine some of the } \\
\text { factors associated with HIVIAIDS-related stigma } \\
\text { among doctors and nurses }\end{array}$ & $\begin{array}{l}\text { Across the different health professionals included in this study, lower levels } \\
\text { of HIVIAIDS knowledge were associated with higher levels of stigmatizing } \\
\text { attitudes toward people living with HIVIAIDS. Stigmatizing attitudes, } \\
\text { including discrimination at work, fear of AIDS, and prejudice, were lower in } \\
\text { health care workers with more experience in treating HIVIAIDS patients }\end{array}$ \\
\hline 10 & $\begin{array}{l}\text { Opollo and Gray, } \\
\text { 2015. Kenya [18] }\end{array}$ & $\begin{array}{l}76 \text { HIV-infected health care } \\
\text { workers in Kisumu, Kenya }\end{array}$ & $\begin{array}{l}\text { Study explored stigma as perceived, } \\
\text { experienced, and managed in HIV-infected } \\
\text { health care workers in Kisumu, Kenya }\end{array}$ & $\begin{array}{l}\text { Two negative themes (blame, lack of knowledge) and five positive themes } \\
\text { (living positively, optimism, empathy, support, and changes overtime). } \\
\text { Three themes emerged on reducing stigma (normalizing, empowerment, } \\
\text { leading by example). Three themes emerged on reducing stigma } \\
\text { (normalizing, empowerment, leading by example) }\end{array}$ \\
\hline 11 & $\begin{array}{l}\text { Nina Sommerland, } \\
2019 . \\
\text { South Africa [19] }\end{array}$ & $\begin{array}{l}882 \mathrm{HCWs} \text { from eight } \\
\text { hospitals was surveyed in } \\
\text { the Free State, South Africa }\end{array}$ & $\begin{array}{l}\text { This study explored factors associated with HIV } \\
\text { stigma toward colleagues }\end{array}$ & $\begin{array}{l}\text { There was a significant negative relationship between stigmatizing attitudes } \\
\text { against other co-workers and knowing a colleague living with HIV, having } \\
\text { a colleague who worked to reduce stigma in the workplace, and having } \\
\text { basic HIV knowledge. Our results have implications for understanding and } \\
\text { crafting interventions to reduce HIV stigma among HCWs }\end{array}$ \\
\hline 12 & $\begin{array}{l}\text { Fauk, } 2021 . \\
\text { Yogyakarta. } \\
\text { Indonesia [20] }\end{array}$ & $\begin{array}{l}\text { Using in-depth interviews } \\
\text { with } 92 \text { PLWHA ( } 52 \text { women, } \\
40 \text { men) and } 20 \text { health-care } \\
\text { providers }\end{array}$ & $\begin{array}{l}\text { This paper describes perspectives and personal } \\
\text { experiences of the } 20 \text { health-care providers, } \\
\text { relating to HIV stigma and discrimination toward } \\
\text { PLWHA in both study settings }\end{array}$ & $\begin{array}{l}\text { Some health-care providers reported that they had personally stigmatized } \\
\text { and discriminated against PLWHA. A lack of knowledge about HIV, fear } \\
\text { of contracting HIV, personal values, religious thoughts, and sociocultural } \\
\text { values and norms were reported as drivers or facilitators behind this HIV- } \\
\text { related stigma and discrimination }\end{array}$ \\
\hline 13 & $\begin{array}{l}\text { Reyes-Estrada } \\
\text { et al., 2018. } \\
\text { Puerto Rico [21] }\end{array}$ & $\begin{array}{l}\text { This study inducted } 40 \\
\text { in-depth interviews with } \\
\text { nurses who provided } \\
\text { services to PWHA }\end{array}$ & $\begin{array}{l}\text { This study aimed to explore the role of religion } \\
\text { in the stigmatization of PWHA by nurses in } \\
\text { Puerto Rico }\end{array}$ & $\begin{array}{l}\text { Three main factors emerged in the analysis as contributors to HIV/AIDS } \\
\text { stigmatization: (1) Nurses' personal religious experiences, (2) religion as } \\
\text { a rationale for HIV-related stigma, and (3) religious practices during health } \\
\text { care delivery. The results show that religious beliefs play a role in how } \\
\text { nurses understood HIVIAIDS and provided service }\end{array}$ \\
\hline 14 & $\begin{array}{l}\text { Xie et al., } 2019 . \\
\text { China [22] }\end{array}$ & $\begin{array}{l}349 \text { medical Staff from } 52 \\
\text { hospitals }\end{array}$ & $\begin{array}{l}\text { The study aimed to validate the health-care } \\
\text { provider HIVIAIDS stigma scale among medical } \\
\text { staff in China }\end{array}$ & $\begin{array}{l}\text { The discrimination factor showed identical means between Canadian } \\
\text { medical students and Chinese medical staff, while the prejudice and } \\
\text { stereotype factors had higher mean scores in the Chinese sample. The } \\
\text { three-factor structure of health-care provider HIVIAIDS stigma scale was } \\
\text { confirmed in Chinese medical staff with a simpler solution. This could } \\
\text { provide a basis for trans-cultural application and comparison }\end{array}$ \\
\hline
\end{tabular}

blame associated with AIDS [19], [28]. The results of Masoudnia's (2015) study show that there is a significant negative correlation between citizen awareness about HIVIAIDS, HIV-related attitudes, negative perceptions of people with HIVIAIDS symptoms, and discriminatory attitudes toward PLWHA $(p<0.01)[29]$.

\section{Level of education}

Chambers (2015) states that the type of health worker according to their educational background affects the stigma and discrimination scores against PLWHA [25]. Another study also stated that educational attainment ( $F$ statistic: 13.8; $4 \mathrm{df} ; \mathrm{p}<0.001$ ) was associated with stigma scores after controlling for all confounding variables. The results of statistical analysis showed that there was no significant relationship between education and stigma among PLWHA [17]. In the learning process, all nurses and midwives are equipped with knowledge and skills according to professional competencies/ standards, especially in providing services to PLWHA. However, the reality is that after they graduate and get a diploma, they are not automatically able to enter the ministry [18], [20].

\section{Length of work}

The length of time a health worker works or does a certain type of work are stated in the length of time he/she performs the task. The development of behavior and attitudes of health workers in decision-making 
Table 2: Summary on determinant related stigma on health care workers

\begin{tabular}{|c|c|c|}
\hline Author/years/country & Design study & Determinant stigma \\
\hline Tran et al., 2019. Vietnam [8] & $\begin{array}{l}\text { Bivariate and } \\
\text { multivariate logistic } \\
\text { regressions. }\end{array}$ & $\begin{array}{l}\text { Socioeconomy status, knowledge, } \\
\text { and attitude }\end{array}$ \\
\hline Xie et al., 2018. China [13] & $\begin{array}{l}\text { Multivariate and } \\
\text { logistic regression } \\
\text { analysis }\end{array}$ & $\begin{array}{l}\text { Culture, education level, gender, } \\
\text { and knowledge regarding HIVI } \\
\text { AIDS. }\end{array}$ \\
\hline $\begin{array}{l}\text { Nair et al., 2019. Bihar, } \\
\text { India [14] }\end{array}$ & $\begin{array}{l}\text { Multivariate logistic } \\
\text { regression analysis }\end{array}$ & $\begin{array}{l}\text { Perception in regards to HIV; } \\
\text { disclosure of HIV status without } \\
\text { consent; policy or institutional } \\
\text { support. }\end{array}$ \\
\hline $\begin{array}{l}\text { (Yang et al., 2018). } \\
\text { United States. [15] }\end{array}$ & $\begin{array}{l}\text { Multivariate double } \\
\text { regression linear } \\
\text { analysis }\end{array}$ & $\begin{array}{l}\text { Knowledge, prejudice, fear, and } \\
\text { working time. }\end{array}$ \\
\hline $\begin{array}{l}\text { Befekadu et al., } 2017 . \\
\text { South Africa [11] }\end{array}$ & $\begin{array}{l}\text { Multivariate logistic } \\
\text { regression }\end{array}$ & Fear and working time. \\
\hline $\begin{array}{l}\text { Prinsloo et al., } 2017 . \\
\text { South Africa [16] }\end{array}$ & $\begin{array}{l}\text { Quasi-experimental } \\
\text { design on two groups. }\end{array}$ & Training \\
\hline $\begin{array}{l}\text { Jabbour et al., } 2018 . \\
\text { South Carolina [17] }\end{array}$ & Logistical regression. & $\begin{array}{l}\text { Gender, education, and } \\
\text { religiousness }\end{array}$ \\
\hline Vorasane, 2017. Laos. [7] & $\begin{array}{l}\text { The study is a cross- } \\
\text { sectional survey. }\end{array}$ & $\begin{array}{l}\text { Fear infection HIV/institutional } \\
\text { support or standard operating } \\
\text { procedures (SOP) }\end{array}$ \\
\hline $\begin{array}{l}\text { Opollo and Gray, } 2015 . \\
\text { Kenya [18] }\end{array}$ & $\begin{array}{l}\text { Bivariate and multiple } \\
\text { linear regression } \\
\text { analyses }\end{array}$ & $\begin{array}{l}\text { Knowledge and attitude, fear, and } \\
\text { working time. }\end{array}$ \\
\hline $\begin{array}{l}\text { Sommerland, } 2019 \\
\text { South Africa [19] }\end{array}$ & Mixed methods study & $\begin{array}{l}\text { Blame, lack of knowledge, } \\
\text { normalizing, and empowerment }\end{array}$ \\
\hline $\begin{array}{l}\text { Fauk, 2021. Yogyakarta. } \\
\text { Indonesia [20] }\end{array}$ & $\begin{array}{l}\text { Multigroup structural } \\
\text { equation modeling }\end{array}$ & Knowledge and attitude \\
\hline $\begin{array}{l}\text { Reyes-Estrada et al., } 2018 . \\
\text { Puerto Rico [21] }\end{array}$ & $\begin{array}{l}\text { A qualitative } \\
\text { framework analysis }\end{array}$ & $\begin{array}{l}\text { Knowledge and attitude, } \\
\text { sociocultural values, and religion }\end{array}$ \\
\hline Xie et al., 2019. China [22] & $\begin{array}{l}\text { Exploratory study } \\
\text { using qualitative } \\
\text { techniques }\end{array}$ & Religious \\
\hline Tran et al., 2019. Vietnam [8] & Logistics regression & Cultural \\
\hline
\end{tabular}

and health service behavior requires work experience so that it can lead to high self-confidence [15]. The duration of work affects the occurrence of stigma and discrimination because someone who has worked for a long time tends to have broader insight and more experience, where this plays an important role in changing the behavior of a health worker [24].

\section{Training}

Atraining intervention provided to health workers resulted in increased knowledge of HIVIAIDS and increased workers' willingness to provide health services [11]. Training of health workers on HIVIAIDS resulted in not only increased knowledge about HIVIAIDS but also improved attitudes toward PLWHA [7]. In addition, external factors such as experience in participating in HIV training, attending workshops, activeness in participating in organizations, and activeness in accessing information such as from the internet, television, newspapers, radio, and other social networks will also contribute to the emergence of attitudes and characters of nurses and midwives related to stigma in PLWHA [30].

\section{Institutional support}

Institutional factors or health service institutions such as hospitals, primary health-care services, and clinics influence the existence of stigma and discrimination against people with HIVAIDS (PLWHA), including matters related to policy-making, standard operational procedure, provision of facilities, facilities, materials, and personal protective equipment in the treatment of HIVIAIDS patients [31]. Research on the influence of institutional or institutional factors is still rarely conducted when in fact it is very important to legally intervene in the existence of stigma and discrimination against PLWHA by health workers [14], [24].

\section{Religious}

Religion plays an important role in stigmatizing behavior among health workers. Religious thought in Islam and Catholicism that prohibits the use of illegal drugs, sexual relations outside of marriage and considers it as a sin also facilitates stigma and discrimination against HIV by health-care providers. The use of such thinking as a parameter to assess the behavior of PLWHA causes the reluctance of health-care providers to serve, interact, and feel disgusted with HIV patients [21]. This supports the findings of a previous study which reported that the inclusion of personal religious beliefs in the provision of health to PLWHA led to clashes between personal religious values and professional expectations [20].

\section{Sociocultural values}

Community stigma against PLWHA is an assessment that is based on values and norms that are rooted in society. Cultural understanding of disease, fear of disclosure is rooted in cultural responses to epidemic disease. Sociocultural values and norms that do not accept same-sex relationship and perceive it as deviant and contaminated behavior also affect participants' acceptance of HIV-positive patients, treatment, and perceptions of PLWHA or facilitate HIV stigma and discrimination against PLWHA in health-care centers. The sociocultural values possessed by health workers are the driving force for discriminatory and stigmatizing attitudes and behavior toward PLWHA. Values of fidelity in marriage and not accepting cheating behavior in PLWHA who are married because it is considered painful for their partner are some examples of personal values held by some participants in research [20] that supports their discriminatory behavior toward PLWHA. The personal values held by these health workers also seem to lead to a personal assessment that PLWHA deserves infection as a consequence of their own behavior. The assessment appears to strengthen participants' discriminatory treatment of HIV patients [22].

\section{Conclusion}

Stigma is still an important issue in the prevention and control of HIVIAIDS. Determinant 
factors that influence HIV-related stigma among health workers are knowledge of HIVIAIDS, perceptions of PLWHA, education level, length of work, training, institutional support, religious, and sociocultural values.

\section{References}

1. Naseer M, Dailey FE, Al Juboori A, Samiullah S, Tahan V. Epidemiology, determinants, and management of AIDS cholangiopathy:A review. World J. Gastroenterol. 2018;24(7):767-74. https://doi.org/10.3748/wjg.v24.i7.767 PMid:29467548

2. Hemelaar J, Elangovan R, Yun J, Dickson-Tetteh L, Fleminger I, Kirtley S, et al. Global and regional molecular epidemiology of HIV-1, 1990-2015:A systematic review, global survey, and trend analysis. Lancet Infect. Dis. 2019;19(2):143-55.

PMid:30509777

3. World Health Organization. Global Health Observatory (GHO) Data HIVIAIDS. Geneva: World Health Organization; 2019. Available from: https://www.who.int/gho/hiv/en. [Last accessed on 2021 Jan 03].

4. Joint United Nations Programme on HIVIAIDS. Global HIV Statistics. Geneva, Switzerland: Joint United Nations Programme on HIVIAIDS; 2019. Available from: https://www.unaids.org/en/ resources/fact-sheet. [Last accessed on 2021 Jan 11]. https:// doi.org/10.1093/oso/9780190672676.003.0014

5. Van De Vijver DA, Boucher CA. Insights on transmission of HIV from phylogenetic analysis to locally optimize HIV prevention strategies. Curr Opin HIV AIDS. 2018;13(2):95-101. https://doi. org/10.1097/coh.0000000000000443

PMid:29266012

6. Nyblade L, Srinivasan K, Mazur A, Raj T, Patil DS, Devadass D, Radhakrishna $\mathrm{K}$, et al. HIV stigma reduction for health facility staff: Development of a blended learning intervention. Front Public Health. 2018;6:165. https://doi.org/10.3389/ fpubh.2018.00165

PMid:29977887

7. Vorasane S, Jimba M, Kikuchi K, Yasuoka J, Nanishi K, Durham $\mathrm{J}$, et al. An investigation of stigmatizing attitudes towards people living with HIVIAIDS by doctors and nurses in Vientiane, Lao PDR. BMC Health Serv Res. 2017;17(1):125. https://doi.org/10.1186/s12913-017-2068-8

PMid:28183300

8. Tran BX, Than PQ, Tran TT, Nguyen CT, Latkin CA Changing sources of stigma against patients with HIVIAIDS in the rapid expansion of antiretroviral treatment services in Vietnam. Biomed Res Int. 2019;2019:4208638. https://doi. org/10.1155/2019/4208638

PMid:30805364

9. Oke OO, Akinboro AO, Olanrewaju FO, Oke OA, Omololu AS. Assessment of HIV-related stigma and determinants among people living with HIVIAIDS in Abeokuta, Nigeria:A crosssectional study. 2019;7:2050312119869109. https://doi. org/10.1177/2050312119869109 PMid:31448118

10. Darvishi ZA, Doroudi F, Madani N. Fuzzy modeling of the enactment of stigma by healthcare personnel toward people living with HIV in the frame of counterfactual thinking:A mixed-method approach. AIDS Res Hum Retroviruses. 2018;34(9):808-15. https://doi.org/10.1089/aid.2018.0166

\section{PMid:30129774}

11. Wodajo BS, Thupayagale-Tshweneagae G, Akpor OA. HIV and AIDS-related stigma and discrimination in two referral hospitals in Ethiopia. Afr J. AIDS Res. 2017;16(2):137-44. https://doi.org/ 10.2989/16085906.2017.1325755 PMid:28639499

12. World Health Organization. Global Health Sector Strategy on HIV 2016-2021 Towards Ending AIDS, No. June. Geneva: World Health Organization; 2018.

13. Wang $\mathrm{W}$, Wang $\mathrm{Y}$, Xiao $\mathrm{C}$, Yao $\mathrm{X}$, Yang $\mathrm{Y}$, Yan $\mathrm{H}$, et al Psychological pathway to suicidal ideation among structural equation model. Psychiatry Res. 2018;260:255-61. https://doi. org/10.1016/j.psychres.2017.11.077 PMid:29220683

14. NairM, KumarP,PandeyS, HarshanaA, KazmiS, Moreto-PlanasL, et al. Refused and referred-persistent stigma and discrimination against people living with HIVIAIDS in Bihar:A qualitative study from India. BMJ Open. 2019;9(11):e033790. https://doi. org/10.1136/bmjopen-2019-033790

15. Yang L, Wong LY, Grivel MM, Hasin DS, Sciences B. Stigma and substance use disorders: an international phenomenon. Curr Opin Psychiatry. 2018;30(5):378-88. https://doi.org/10.1097/ yco.0000000000000351 PMid:28700360

16. Prinsloo CD, Greeff $M$, Kruger A, Dorothea $C$, Greeff $M$ Kruger A. HIV stigma experiences and stigmatisation before and after a HIV stigma-reduction community "hub" intervention. Afr J AIDS Res. 2017;16(3):203-13. https://doi.org/10.2989/160 85906.2017 .1349683 PMid:28978287

17. Jabbour M, Newton AS, Johnson D, Curran JA. Defining barriers and enablers for clinical pathway implementation in complex clinical settings. Implement Sci. 2018:13(1):139. https://doi. org/10.1186/s13012-018-0832-8 PMid:30419942

18. Opollo JG, Gray J. Stigma in HIV-infected health care workers in Kenya:A mixed-method approach.J Assoc Nurses AIDS Care. 2015;26(5):639-51. https://doi.org/10.1016/j.jana.2014.12.005 PMid:25769752

19. Sommerland N, Wouters E, Masquillier C, Rau A, Engelbrecht M, Kigozi G. Factors associated with HIV-related stigma toward colleagues in the health care workforce in South Africa.J Assoc Nurses AIDS Care. 2019;30(4):451-61. https://doi.org/10.1097/ jnc. 0000000000000010

PMid:31241509

20. Fauk NK, Ward PR, Hawke K, Mwanri L. HIV stigma and discrimination: Perspectives and personal experiences of healthcare providers in Yogyakarta and Belu, Indonesia. Front Med. 2021;8:625787. https://doi.org/10.3389/ fmed.2021.625787

PMid:34055824

21. Reyes-Estrada M, Varas-Díaz N, Parker R, Padilla M, RodríguezMadera S. Religion and HIV-related stigma among nurses who work with people living with HIVIAIDS in Puerto Rico.J Int Assoc Provid AIDS Care. 2018;17:2325958218773365. https://doi. org/10.1177/2325958218773365 PMid:29756551

22. Xie $\mathrm{H}, \mathrm{Yu} \mathrm{H}$, Watson $\mathrm{R}$, Wen J, Xiao L, Yan M, et al. Cross cultural validation of the health care provider HIVIAIDS stigma scale (HPASS) in China. AIDS Behav. 2018;2018:0123456789. https://doi.org/10.1007/s10461-018-2312-1

23. Wilandika A. Assessment of health workers on peoplewith HIV AIDS (PLWHA) in one health center in Bandung. J Nursing. 2019;10:7-15. https://doi.org/10.33867/jka.v6i2.124

24. Nyblade L, Stockton MA, Giger K, Bond V, Ekstrand ML, 
McLean $\mathrm{R}$, et al. Stigma in health facilities: Why it matters and how we can change it. BMC Med. 2019;17(1):25. https://doi. org/10.1186/s12916-019-1256-2

PMid:30764806

25. Bauermeister JA, Budey B, Ehiri JE, Curtis MJ. Stigma, culture, and HIV and AIDS in the Western Cape, South Africa: An application of the PEN-3 cultural model for community-based research collins. AIDS Behav. 2017;23(3):139-48.

26. Kalichman S, Katner H, Banas E, Kalichman M. Population density and AIDS-related stigma in large-urban, small-urban, and rural communities of the Southeastern USA. Prev Sci. 2017;18(5):517-25. http://doi.org/10.1007/s11121-017-0761-9 PMid:28190136

27. Tran BX, Phan HT, Latkin CA, Lan H, Nguyen T. Understanding global HIV stigma and discrimination: Are contextual factors su ffi ciently studied ? (GAP RESEARCH). Int J Environ Res Public Health. 2019;16(11):1899. https://doi.org/10.3390/ijerph16111899 PMid:31146379

28. Subedi B, Timilsina B, Tamrakar AP. Perceived stigma among people living with HIV AIDS in Pokhara, Nepal. HIV AIDS. 2019;11:93-103. https://doi.org/10.2147/hiv.s181231

PMid:31118826

29. Masoudnia E. Public perceptions about HIVIAIDS and discriminatory attitudes toward people living with acquired immunodeficiency syndrome in Iran. Sahara J. 2015;12(1):116-22. https://doi.org/10.1080/17290376.201 5.1123644

PMid:26726933

30. Sudarsono S. Characteristics associated with nurses and midwives stigma in people with HIVIAIDS (PLWHA) in the district health Talun Blitar.J Ners Midwifery. 2015;2(1):30-7. https://doi. org/10.26699/jnk.v2i1.art.p030-037

31. Kabbash IA, Abo Ali EA, Elgendy MM, Abdrabo MM, Salem HM, Gouda MR, et al. HIVIAIDS-related stigma and discrimination among health care workers at Tanta University Hospitals, Egypt. Environ Sci Pollut Res. 2018;25(31):30755-62. https://doi. org/10.1007/s11356-016-7848-x

PMid:27752955 